\title{
DO PRISONERS' LIVES MATTER? EXAMINING THE INTERSECTION OF PUNITIVE POLICIES, RACIAL DISPARITIES AND COVID-19 AS STATE ORGANIZED RACE CRIME
}

\author{
Elizabeth A. Bradshaw
}

\begin{abstract}
Numerous Michigan prisons emerged as national hotspots early in the coronavirus crisis. Once the virus entered the prisons, key actions and inaction by Michigan Department of Corrections and Governor Gretchen Whitmer allowed COVID-19 to flourish unabated, resulting in unnecessary infection and death; a form of cruel and unusual punishment. The callous neglect of the human rights of prisoners during the pandemic is not new, but rather the result of decades of punitive sentencing policies that disproportionately target people of colour. Through a case study examination of early coronavirus outbreaks in Michigan prisons, this paper will consider how Truth in Sentencing legislation, increasingly long prison sentences and declining parole rates, helped set the stage for coronavirus to spread, disproportionately harming Black and elderly prisoners. As the intersecting crises of coronavirus and mass incarceration exemplify, state crime scholars can no longer ignore the state-organized race crime occurring behind prison walls.
\end{abstract}

Keywords: COVID-19; coronavirus; prisons; mass incarceration; Michigan; state-organized race crime

The United States is an outlier when it comes to the spread of COVID-19 internationally, with the country topping the charts for the total number of positive cases and deaths. Similarly, the country also leads the world in the number of people incarcerated in prisons, jails and detention facilities. The intersecting crises of COVID-19 and mass incarceration have culminated into an epidemic of racialized disparities that have disproportionately impacted Black and elderly prisoners. As the Center for Disease Control and Prevention (CDC) acknowledges, correctional facilities face particular challenges in controlling the spread of highly infectious pathogens like COVID-19 such as "crowded dormitories, shared lavatories, limited medical and isolation resources, daily entry and exit of staff members and visitors, continual introduction of newly incarcerated or detained persons, and transport of incarcerated or detained persons in multi-person vehicles for

Elizabeth A. Bradshaw, Central Michigan University, USA 
court-related, medical, or security reasons" (Wallace et al. 2020: 587). Overcrowded conditions of confinement that are commonplace across U.S. prisons and jails make it impossible to abide by the social distancing guidelines of six feet prescribed by the CDC. Comparing them to nursing homes or cruise ships, which saw early rampant infections due to close quartering, the president of the Cook County Board of Commissioners perceptively noted "[o]ur jails are petri dishes" (Williams et al. 2020).

National estimates on the spread of coronavirus behind bars have examined positive case rates and death among U.S. federal and state prisoners, despite the difficulties in obtaining data from state agencies. Saloner et al. (2020: E1) found that prisoners are experiencing higher positive rates and deaths than the general population:

By June 6,2020 , there had been 42,107 cases of COVID-19 and 510 deaths among $1,295,285$ prisoners with a case rate of 3,251 per 100,000 prisoners. The COVID19 case rate for prisoners was 5.5 times higher than the US population case rate of 587 per 100,000. The crude COVID-19 death rate in prisons was 39 deaths per 100,000 prisoners, which was higher than the US population rate of 29 deaths per 100,000 .

Likewise, researchers have identified over 570 incarcerated people and more than 50 correctional staff who have died across the United States as of June 22, 2020 (Widra and Hayre 2020). Noting the inconsistency of state agency data, non-profit organizations such as the Marshall Project's (2020) "State-by-State Look at the Coronavirus in Prisons" and the UCLA Prison Law and Policy Program's (2020) "Covid-19 Behind Bars Data Project" have also created databases to track the spread of the virus in U.S. prisons. Furthermore, researchers with the Marshall Project received few responses to requests for state data on the racial demographics of incarcerated persons infected with COVID-19, with many states unable or unwilling to provide data (Chammah and Meagher 2020).

The report Failing Grades: States' Responses to COVID-19 in Jails and Prisons published at the end of June 2020 by the American Civil Liberties Union and Prison Policy Initiative (Widra and Hayre 2020) found that most states have taken very little action to address the pandemic inside prisons. To assess each state's response, the report considered whether: testing and personal protective equipment were provided to correctional staff and prisoners; the state reduced jail and prison populations; the governor issued executive orders for accelerated release of the medically vulnerable or those nearing completion of their sentence; and whether the state published regularly updated publicly available data on COVID-19 in the state prison system. Only five states (Massachusetts, Michigan, 
Tennessee, West Virginia and Vermont) had completed comprehensive testing of the population in state prisons. Only three states (New Mexico, Massachusetts and West Virginia) additionally completed comprehensive testing of staff. Based on these metrics, no state scored above a "D-" on their response, with Tennessee, Michigan, Kentucky, Vermont, West Virginia, Colorado, Minnesota, Oregon and Maine ranking at the top (Widra and Hayre 2020).

Despite ranking at the top of the class, Michigan's response to the coronavirus pandemic inside its prison warrants a failing grade. The state experienced an early and severe outbreak of COVID-19 inside nearly a dozen of its correctional facilities. Numerous Michigan Department of Corrections (MDOC) facilities quickly became national hotspots, including Lakeland, Parnall and Cotton Correctional Facilities. Exceeding the infection rates in prisons and jails in New York and Chicago, in mid-April 2020 Parnall Correctional Facility emerged as a national COVID-19 hotspot with 10 percent of prisoners and 21 percent of staff testing positive (Jackson and Tanner 2020a). During the last week in April, Lakeland Correctional Facility, which primarily houses geriatric prisoners, had the ninth largest known coronavirus cluster of confirmed cases in the country, while Parnall Correctional Facility ranked as the eleventh largest cluster nationwide (Jackson and Tanner 2020b). By early May 2020, Michigan had the highest prisoner death rate across the country and the third highest number of positive cases, even higher than the federal prison system which houses a population five times larger (Jackson and Tanner 2020c). Because of the early emergence of COVID-19 throughout the MDOC system, Michigan provides an important case study in examining the state's response to the pandemic that impacted the most vulnerable citizens under its care; disproportionately elderly, Black prisoners.

Alleging that the MDOC violated the Eighth Amendment against cruel and unusual punishment by failing to follow the CDC's COVID-19 Guidelines for Prisons, on April 29, 2020 six prisoners filed a federal lawsuit against MDOC Director Heidi Washington and the wardens of four facilities. In the initial months of the pandemic prior to systematic testing, Macomb, Cotton, Parnall and Lakeland Correctional Facilities recorded the highest percentages of inmates testing positive for COVID-19. Although the MDOC issued policies to address the spread of the virus, the lawsuit maintains that critical recommended guidelines for controlling the disease were not followed, such as widespread testing, social distancing and separation of inmates who test positive from those who are not positive. The plaintiffs described conditions of confinement that make it impossible to practice social distancing. For example, Macomb Correctional Facility includes numerous cells for double occupancy and some cells do not have their own bathrooms, forcing prisoners to rely on community bathrooms at the end of each wing of the prison. According to the lawsuit, there is no social distancing or 
regular cleaning of commonly used areas including bathrooms, chow halls, phones and computer kiosks. Constructed decades ago as "temporary" housing, at Cotton and other facilities across the state, prisoners are confined in a pole barn containing dormitory style housing in which eight men live within a 10 by 12 foot space. "It is physically impossible for eight people to maintain six feet of social distancing in an area measuring $10 \times 12$ feet" (Abrams et al. vs. Chapman et al. 2020: 9). The low dividing walls inside the pole barn further allow for the free flow of air, and coronavirus, between cubes. Each pole barn houses a total population of 160 inmates and has two bathrooms, each with three showers, three urinals and four toilets. At multiple facilities, prison staff perform inmate patdowns either without gloves or without changing gloves between procedures (Abrams et al. vs. Chapman et al. 2020). Existing long before the most current pandemic, overcrowded, unsanitary conditions that facilitate the spread of COVID-19 are not unique to these four prisons, but instead are common across MDOC facilities.

As mass testing would reveal, by the start of June the virus had infiltrated numerous other MDOC facilities, infecting large proportions of prisoners and staff. Significant coronavirus outbreaks thrived in 11 of 29 MDOC facilities, which housed more than 3,896 of the total 3,918 positive prisoner cases. Located in the southeast quadrant of the state, infections in these facilities comprised 99 percent of all positive MDOC cases. Mandatory nasal swab testing unveiled high positive rates for COVID-19 infection at Lakeland (56 percent), Cotton (37 percent), Gus Harrison (37 percent), Parnall (31 percent) and Thumb (29 percent). Furthermore, optional coronavirus antibody testing for prisoners demonstrated high positive rates across the 11 facilities, meaning significant numbers of prisoners had previously contracted the virus. At Parnall, where most prisoners volunteered to be tested, 92 percent were positive for coronavirus antibodies. Similarly high positive antibody rates were found at Lakeland (74 percent) and Macomb (66 percent), while multiple other correctional facilities registered a third of prisoners testing positive for antibodies. Within the two months between when the first prisoner and staff deaths occurred on April 1, and when the number of prisoner deaths stabilized on June 2, there were a total of 68 prisoner and two staff deaths from COVID-19. Mirroring the racial disparities of the Michigan prison population more broadly, over 53 percent of the positive prisoner cases and nearly half of the total prisoner deaths from COVID-19 were people of colour, particularly African Americans. Furthermore, most deaths occurred among prisoners over age 50 and nearly a third of deaths were concentrated within geriatric units at Lakeland Correctional Facility.

The current crisis of COVID-19 provides an opportunity to reflect on how decades of punitive policies created a crisis of mass incarceration with all its racial 
disparities, thus setting the stage for the current pandemic to exacerbate an already critical situation. A published letter written by an anonymous Arab American prisoner incarcerated in the MDOC astutely describes the problem as follows:

The prison system in Michigan is in dire straits, and this is sadly not only due to the COVID-19 pandemic; it has actually been this way for a long time. COVID-19 was the catalyst that exposed the flaws and mismanagement the MDOC has been experiencing for years, even decades. Although capital punishment was abolished in the state of Michigan decades ago, the MDOC has now effectively and singlehandedly reinstated the death penalty, usurping the voice of the people of the great state of Michigan. To date, there have been close to [70] inmate deaths related to COVID-19, some of whom were due to parole within a few weeks or months. These deaths could have been avoided if $M D O C$ policies were based on sound scientific methods (ABBAS 2020).

Even before the era of COVID-19, widespread human rights abuses were occurring inside prisons and detention facilities across the United States. The pandemic has provided the opportunity to shed light on the cruel and unusual treatment occurring behind prison walls. As the American Civil Liberties Union (2020) explains,

the COVID-19 pandemic is exposing the rampant inequities within society's institutions, such as U.S. correctional facilities. Its disproportionate impact on the Black community underscores the existing racial disparities within American criminal law and American health care. Moreover, COVID-19 is highlighting the extent to which these systems are infected by, and driven by, deep systemic racism.

The persistent racial disparities throughout the U.S. criminal justice system are not new and are the result of decades of punitive sentencing policies such as Truth in Sentencing laws, the increasing use of life sentences and declining parole rates. Punitive policies such as these have led to prison overcrowding in Michigan and across the country, contributing to the conditions that allow the virus to flourish. Despite pervasive systemic racism in mass incarceration, state crime scholars have devoted scant attention to the human rights violations occurring within U.S. prisons and jails and have instead defined torture as something that happens elsewhere. As coronavirus continues to spread like wildfire through U.S. prisons killing the most vulnerable, state crime scholars can no longer ignore the human rights nightmare that is occurring on our watch. To understand the role of the state in aiding and abetting the conditions allowing for racism to flourish, it is necessary to explore the interconnectedness between history, governmental policy and the current pandemic. 


\section{A Human Rights Nightmare is Occurring on Our Watch: Racial Disparities in Mass Incarceration}

The United States incarcerates more people in prisons, jails and detention centers than any other country in the world. The country represents less than 5 percent of the world's total population, yet is home to 20 percent of the world's incarcerated people. According to the Prison Policy Initiative,

[t]he American criminal justice system holds almost 2.3 million people in 1,833 state prisons, 110 federal prisons, 1,772 juvenile correctional facilities, 3,134 local jails, 218 immigration detention facilities, and 80 Indian Country jails as well as in military prisons, civil commitment centers, state psychiatric hospitals, and prisons in the U.S. territories (Sawyer and Wagner 2020).

Imagining every state as an independent nation and comparing the incarceration rates of U.S. states to other countries, Wagner and Sawyer (2018) find that every state incarcerates people at a higher rate than nearly every other country on earth. The least punitive U.S. states rank alongside countries with authoritarian governments and those recently experiencing wide-scale violent domestic armed conflicts. Compared to stable democratic countries, the use of incarceration in the United States is both exponential and exceptional.

Racial disparities are a defining feature of the U.S. criminal justice system. The Sentencing Project identifies four key features of the criminal justice system that exacerbate underlying socioeconomic and racial inequity. First, many seemingly race-neutral policies have a disparate racial impact on communities of colour. This includes police policies such as stop and frisk and "broken windows," as well as prosecutorial policies such as plea bargaining guidelines and harsh sentencing laws. Second, criminal justice practitioners' use of discretion is, often unintentionally, influenced by racial bias. Third, key segments of the criminal justice system such as indigent defense, pretrial release, parole and probation, and public drug treatment programs are underfunded, thereby putting Blacks and Latinos (who are disproportionately low income) at a disadvantage. Finally, criminal justice policies worsen socioeconomic inequalities by imposing collateral consequences, such as barriers to employment, public assistance and public housing, on those with criminal records and by diverting public spending (Ghandnoosh 2014: 3). As a result of accumulating racial disadvantage at every step of the justice process, "“Black lives matter' has become a rallying cry in light of evidence that the criminal justice system is failing to uphold this basic truth" (Ghandnoosh 2014: 3).

Across the United States, African Americans are incarcerated in state prisons at a rate more than five times the imprisonment rate of Whites. Led by Maryland, 
whose prison population is 72 percent Black, in 12 states more than half of the prison population is Black (Alabama, Delaware, Georgia, Illinois, Louisiana, Maryland, Michigan, Mississippi, New Jersey, North Carolina, South Carolina and Virginia). The Bureau of Justice Statistics reports that 35 percent of state prisoners are White, 38 percent are Black and 21 percent are Hispanic (compared nationally to the general population 76 percent, 13 percent and 19 percent, respectively) (Nellis 2016). Further contributing the problem of racial disparities in mass imprisonment, a record number of people in the United States are serving life sentences (with and without parole) and "virtual life" sentences (more than 50 years), representing 13.9 percent of the total U.S. prison population. Of this total, two-thirds are people of colour, including 48 percent who are African American (Nellis 2017).

Driven primarily by the war on drugs, Alexander (2012) argues that mass incarceration has emerged as a new form of racialized social control similar to the previous racial caste systems of Jim Crow segregation and slavery. "Like Jim Crow (and Slavery), mass incarceration operates as a tightly networked system of laws, policies, customs, and institutions that operate collectively to ensure the subordinate status of a group defined largely by race" (Alexander 2012: 13). At its core, mass incarceration is a "race-making" institution that functions to define the meaning and significance of race in America. Crime and race have become synonymous, so that Black men in particular are stigmatized as criminal. Once someone is labeled a felon, old forms of discrimination in employment, housing, voting, education, public benefits and jury service suddenly become legal again. More than a system of crime control, the stigma of incarceration establishes an undercaste of individuals who are permanently prohibited by law and custom from participating in mainstream society. Unlike previous state-sponsored racial caste systems, mass incarceration has been largely immunized from legal challenge in the era of colorblindness. Even within the civil rights community, there was initial reluctance to view mass incarceration through the lens of racial justice. "After all, criminals are the one social group in American that nearly everyone-across political, racial, and class boundaries - feels free to hate" (Alexander 2012: 228). Since the publication of The New Jim Crow, widespread advocacy and action towards ending mass incarceration has blossomed, yet there remains much work to be done. Alexander's (2012: 15) words are even truer today in the era of COVID-19: "A human rights nightmare is occurring on our watch."

\section{Torture Happens Elsewhere: State Crime Research on the Abuse of Prisoners}

Within the literature on state crime, there are few studies that explore mass incarceration and the human rights abuses occurring inside U.S. jails and prisons as examples of state criminality. Synthesizing state harm at the intersection 
of the military and prison industrial complexes, Bradshaw (2019) identifies forced exposure to environmental toxins during incarceration as a form of "green state crime" (Moloney and Chambliss 2014). Across the United States, correctional facilities are frequently built on or near environmentally contaminated land, including former military bases, a phenomenon known as toxic prisons. Through a case study of the human rights abuses against noncriminal immigrant detainees incarcerated at a federal prison complex located on a toxic Superfund site at a former military base, Bradshaw (2019) sheds light onto a unique form of green state crime perpetrated disproportionately against minorities: "The disparate racial composition of the prison population coupled with persistent environmental injustices at correctional facilities amount to a nationwide epidemic of toxic prisons" (2019: 141). Beyond this study, state crime scholars have neglected to explore the racism and human rights violations happening inside U.S. jails and prisons.

Detailing the long history of state-sponsored violence against African Americans, Ward (2015) examines the "slow violence" of state-organized race crime. Slow violence, as Nixon (2011:2) defines it, is "violence that occurs gradually and out of sight, a violence of delayed destructions that is dispersed across time and space, an attritional violence that is not typically viewed as violence at all." State-organized race crime embodies many dynamic forms and occurs when state actors and institutions commit or abet racial violence, conceptualize and regulate race-related violence or other harm, and criminalize racially defined groups (Ward 2015: 300). Focusing on the racial violence of state actors and institutions, Ward (2015: 300) explains that "these forms of state-organized race crime are ultimately intertwined in social and historical relationships, bound together as cycles of under-regulated racial violence, and rationalized in part by the criminalization of race." Employing physical abuse and structural deprivation to establish and maintain racial domination and subordination, state actors and institutions have a long history of engaging and promoting racial violence ranging from the state-sponsored racial terror of lynching, to more contemporary examples of violence and stratification in the forms of corrupted crime data, distrust of police, racial resentment, generational poverty and work opportunities. In contrast to spectacular forms of state violence like lynchings or police shootings, state-organized race crime is typically characterized by more subtle forms of structural violence in which victimization is delayed, dispersed and hidden, resulting in disaccumulation, collective underdevelopment and intergenerational disadvantage. "Mass incarceration and the resulting social exclusion," Ward (2015: 307) contends, "is a foremost crisis of state organized race crime today." In tandem with Alexander's (2012) contention that mass incarceration is the most recent state-sponsored racial caste system, Ward's (2015) 
assessment of the slow violence of state organized race crime is well suited for understanding how decades of punitive sentencing policies culminated into pervasive racial disparities in incarceration rates.

State crime scholars such as Rothe (2006), Rothe, Kramer and Mullins (2009) and Smeulers and van Niekerk (2009) have extensively documented and theorized the human rights abuses committed by American soldiers against Iraqi citizens incarcerated at the Abu Ghraib prison in Iraq. Far from simply the individual actions of a few rogue soldiers, these studies reveal that the torture, abuse and mistreatment of prisoners at Abu Ghraib was a clear example of state-organized crime that reached to the top levels of the Pentagon and White House. Embracing the standards of international law, Rothe, Kramer and Mullins (2009) argue that under the III Convention of the Geneva Conventions of 1949 (relative to the Treatment of Prisoners of War), prisoners should be treated humanely, provided with adequate housing, food, clothing and medical care. The Convention furthermore prohibits torture, medical experimentation, acts of violence, insults and public curiosity against those who are captured. Despite applying these standards to the U.S. torture of prisoners abroad, state crime scholars have not applied those same standards to incarcerated persons domestically. As human rights are generally thought to only apply abroad, Labelle (2008) urges us to bring the concept and value of human rights "home" and apply them to incarcerated persons in the United States.

Drawing parallels between the war on terror and the war on crime, Gordon (2006) argues that the actions and policies of military prisons such as Abu Ghraib reflect accepted norms within civilian prisons. "Excessive force, civil disability and the loss of internationally guaranteed rights, and indefinite detention are central means by which the wars on both terror and crime (civilian mass imprisonment) are executed" (Gordon 2006: 42). U.S. military prison and U.S. civilian prison personnel overlap significantly through military police units and reserve National Guard forces who utilize their experience in domestic prisons abroad and vice versa. Key individuals convicted in the abuse at Abu Ghraib even had prior histories of violence against prisoners while working as civilian correction officers in state prisons back home. According to FBI reports, none of the soldiers witnessing abuse and torture at Abu Ghraib defined it as mistreatment based on the procedures used by guards in U.S. prisons and jails, but instead saw it as acceptable prison guard behavior. Reflecting the dehumanization that is the modus operandi of the modern prison, Gordon (2006: 48) argues "Torture, humiliation, degradation, sexual assault, assault with weapons and dogs, extortion, and blood sport always have been part of US prison culture and behavior." Combined with systemic racial disparities in incarceration, institutionalized abuses such as these indicate that "racialized sadism" is routine inside U.S. prisons (Gordon 2006: 49, quoting William Pinar). 


\section{In Michigan, Life Means Life: Truth in Sentencing, Mass Incarceration and the Slow Violence of State-Organized Race Crime}

The slow violence of decades of racially disparate punitive policy decisions that caused prison overcrowding and paved the way for widespread infection contrasts with the rapid proliferation of the virus behind prison walls. Unfolding since the "tough on crime" era began in the 1970s, Michigan's punitive policies such as Truth in Sentencing legislation, longer prison sentences and reduced parole rates are important factors in understanding the spread of coronavirus in the state's prisons. As Mauer and Nellis (2018: 25) stress, "[p]olicy choices, not criminal offending patterns, have produced the dramatic expansion in both the number of people serving life imprisonment and the years they must serve before being considered for release." Specific decisions by the state's legislature and governor more than 30 years ago have contributed to the intersecting crises of mass incarceration and COVID-19 in Michigan's prison system.

In 1998, the Michigan legislature adopted one of the most punitive Truth in Sentencing (TIS) laws in the country, requiring prisoners to serve their entire minimum sentence before being eligible for parole. "The state set time-served requirements before eligibility for parole consideration to 100 percent of the minimum sentence (instead of 85 percent) and applied it to all sentences (instead of just sentences for violence)" (Schrantz et al. 2018: 17, emphasis in original). TIS legislation led to an elimination of good-time reductions, a decrease in sentence for demonstrating good behavior, for most prisoners by 1998 and all prisoners by 2000. Perhaps predictably, these changes caused Michigan's prison population to grow from 38,628 in 1992 to a peak of 51,454 in 2006 (Yantus 2017: 147). During this time, the number of people entering Michigan prisons did not change, yet the number of parole denials increased, resulting in prisoners serving longer amounts of their sentences before being released on parole (Yantus 2017).

Following a 1992 change to the composition of the parole board from civil service employees to political appointees selected by the governor, the Michigan parole board began incarcerating more people for longer periods of time in the name of public safety. Within an increasingly conservative political climate, the parole board embraced the position that "life means life" and slashed parole consideration for those given life with the possibility of parole sentences (Mauer and Nellis 2018). Representing 13.5 percent of the Michigan's total prison population, in 2016 there are 1,317 people serving life without parole, 3,804 serving life with parole and 590 serving virtual life (more than 50 years), including more than 500 juvenile lifers. Of the total number of prisoners serving life and virtual life 
sentences in Michigan, 65.8 percent are Black, while only 33 percent are White, with African Americans making up more than 68 percent of all life without parole prisoners (Nellis 2017).

Michigan leads the country in the average length of prison stay as a result of amendments to the sentencing guidelines, legislative revisions of maximum penalties, expanded authority for consecutive sentencing and newly expanded harsh mandatory minimum terms. Reflecting increasing penalties within the Michigan system over time, between 1999 and 2009 the average sentence length almost doubled (Yantus 2014: 646). While the 2009 national average for years served in prison was 2.9 years, in Michigan it was 4.3 years. The average length of sentence within the state increased over time from 2.4 years in 1990 to 4.3 years in 2009 . For violent offenders, the average minimum length of stay increased from 3.9 years in 1990 to 7.6 years in 2009, longer than any other state. Even for drug offenders, those released in Michigan served the third longest average time in custody (2.9 years in 2009, up from 1.7 years in 1990). Furthermore, one analysis of non-violent offenders released in Michigan found that 24 percent could have served shorter prisoner terms between three months and two years without posing a threat to public safety and saving $\$ 92$ million on incarceration costs (Pew Center on the States 2012).

With more prisoners serving life and virtual life sentences and limited use of early release, state and federal prisons are increasingly responsible for a graying prison population with significant pre-existing conditions. Pre-existing health conditions are more prevalent among prison and jail inmates than across the general population in the United States. In 2011-2012, half of state and federal prisoners and jail inmates reported having a chronic condition (including cancer, high blood pressure, stroke-related problems, diabetes, heart-related problems, kidneyrelated problems, arthritis, asthma and cirrhosis of the liver), while 21 percent of prisoners and 14 percent of jail inmates reported having an infectious disease (U.S. Department of Justice 2015).

Correctional facilities were never designed to be nursing homes equipped to serve the needs of an aging prison population, making incarceration especially punishing for the elderly (Fellner 2015). As Human Rights Watch (2012: 4) explains:

Prisons in the United States contain an ever growing number of aging men and women who cannot readily climb stairs, haul themselves to the top bunk, or walk long distances to meals or the pill line; whose old bones suffer from thin mattresses and winter's cold; who need wheelchairs, walkers, canes, portable oxygen, and hearing aids; who cannot get dressed, go to the bathroom, or bathe without help; and who are incontinent, forgetful, suffering chronic illness, extremely ill, and dying. 
Between 1993 and 2013, the number of state prisoners age 55 or older doubled each decade, increasing a total of more than 400 percent. In 2013, almost one third of the oldest offenders (age 65 or older) were serving life sentences or death (U.S. Department of Justice 2016). According to one conservative estimate, the United States spends at least $\$ 16$ billion annually on incarcerating approximately 250,000 people over age 50, even though people in this age group pose the least risk to society and are least likely to reoffend (Bunting 2015).

Within the MDOC, nearly one quarter (23.2 percent) of Michigan's prison population of approximately 38,000 is over age 50 and about 800 people are considered medically frail (Safe and Just Michigan 2019). There are nearly 1,700 people in prison beds needing geriatric care, dialysis or other forms of chronic medical care, mental health stabilization and residential treatment, and dementia care (Levine 2015). The average annual health care costs for prisoners in Michigan has been estimated at $\$ 5,801$, with the costs for those who are younger (age 34 or under) being $\$ 4,200$ or less and the costs for older prisoners (age 55 or older) ranging from $\$ 11,000$ to $\$ 40,000$ (Angelotti and Wycoff 2010: 15).

Regardless of their physical or mental state, MDOC has no authority to release vulnerable and medically frail prisoners since Michigan's TIS law requires prisoners to serve 100 percent of their minimum sentence before they can be released. Notwithstanding recent thwarted efforts of citizen ballot initiatives to repeal TIS legislation, an executive order from the governor lifting the TIS law is the only mechanism for releasing vulnerable prisoners during the pandemic (LeBlanc 2020). Although executive orders from Governor Whitmer strongly encouraged county jails to consider early release for older people, those with chronic conditions, pregnant women and people nearing their release date as a means of mitigating COVID-19, these guidelines did not apply to persons incarcerated in state prisons (State of Michigan 2020). Even though governors in other states issued executive orders calling for the release of medically vulnerable people or those nearing completion of their sentence, the governor did not use her executive authority to encourage the release of Michigan prisoners, thereby leaving the state's Truth in Sentencing law as a barrier to release for many.

\section{Assessing Michigan's Failing Response to Coronavirus Behind Bars}

Once the virus entered Michigan prisons, a number of crucial mistakes by the MDOC allowed the virus to flourish undetected for months before action was taken. In addition to the physical impossibility of abiding by social distancing guidelines inside prisons, key MDOC policies such as ongoing prisoner transfers, incorrectly reporting test results to prisoners, and delayed testing for prisoners and 
staff, all resulted in unnecessary exposure, infections and deaths from COVID-19. While Michigan was one of the first states to test all its prisoners, the decision to embark on systematic testing was a measure of last resort. By the time facilities with outbreaks were tested, the majority of prisoners had already contracted the virus, as nasal swab and antibody testing demonstrated. Mimicking the racial disproportionalities of the Michigan prison system more generally, approximately half the positive COVID-19 cases and deaths occurred among Black prisoners. Finally, posing a continuing risk to prisoners, staff and the community, MDOC's reluctance to implement consistent testing for staff has facilitated the spread of the virus within and between facilities.

The first presumptive positive cases of COVID-19 in the State of Michigan were identified on March 10, 2020 by the Michigan Department of Health and Human Services. In response, Governor Gretchen Whitmer declared a state of emergency across the state, issuing a cascade of executive orders that expanded state government powers to address the pandemic. Issued on March 29, Executive Order 2020-29 (EO 2020-29) required the MDOC to implement "risk reduction protocols" including: scanning all persons entering and departing from facilities; restricting all visits (exempting attorney-related visits); limiting off-site appointments; developing and implementing protocols for incarcerated persons displaying symptoms of COVID-19; providing personal protective equipment to staff; regular stringent cleaning; ensuring access to personal hygiene products to prisoners and staff for handwashing; implementing protective laundering protocols; posting signage and educating on hygiene and importance of social distancing; practicing social distancing (e.g. six feet between persons) in any meeting, classroom or other group; and minimizing crowding (State of Michigan 2020).

On March 13, 2020, the MDOC halted in-person visits for prisoners, including outside volunteers, tours and other groups entering the prisons and also began screening staff by asking questions and providing temperature checks prior to entering the prison (Michigan Department of Corrections 2020a). Even though MDOC suspended visits from loved ones and volunteers, substance abuse classes and face-to-face General Education Development (GED) classes continue to be offered, permitting counselors and teachers to enter facilities. Even though reduced class sizes were implemented, it remains impossible to abide by social distancing guidelines. Since prisoners cannot by law be released until they have completed the high school equivalency certificate, MDOC argues that it is necessary to continue offering classes. However, some teachers express concern that MDOC is not taking the necessary precautions to halt the spread of the virus, putting the lives of prisoners, staff and community members at risk (Samilton 2020a).

The first two positive cases of COVID-19 among MDOC staff were reported by a Jackson County probation officer and an employee at the Detroit Detention 
Center on March 17, 2020 (Michigan Department of Corrections 2020b). Shortly thereafter, the MDOC was notified on March 22 of the first positive case of COVID-19 after a prisoner housed at Kinross Correctional Facility (located in Michigan's rural Upper Peninsula) was transferred to a hospital in northern Lower Michigan to receive treatment for a medical condition. By that time, three MDOC employees, all in different locations, had already tested positive (Jackson and Egan 2020). Just over a week later on April 1, the first MDOC prisoner died in his cell of coronavirus without previously informing health care workers he was sick and only later testing positive at the hospital (Rahal 2020). On the same day, the first MDOC employee, a transportation officer from Detroit, also died from COVID-19 (Llanes 2020). In the two months that followed between April and June, the infection rate and death toll rose dramatically across facilities due to crucial mistakes made by MDOC.

Contributing to the pervasive spread of COVID-19 through the MDOC system, throughout the pandemic MDOC continued to transfer prisoners between facilities even when they tested positive for COVID-19 or had been housed alongside someone testing positive. After testing positive for the virus, prisoners from across the state were quarantined in two facilities: Carson City and Cotton Correctional Facilities, which initially had no positive cases when the COVID-19 units were established (Egan and Jackson 2020). MDOC's policy of transferring prisoners during the pandemic resulted in errors that resulted in unnecessary exposure. For example, on May 1, 2020 due to a lab mix-up, three prisoners from Egeler Reception and Guidance Center with COVID-19 were mistakenly transferred to Central Michigan Correctional Facility (CMCF) that had previously reported no cases of the virus (Agar 2020). In an email to MDOC officials, Garcia Laboratory (2020) said the issue was caused by an error when transferring optical plates from the extraction platform to the thermocycler and assured the MDOC that technologists had been given proper instruction to prevent future occurrences. Although those with close contacts to infected prisoners were isolated, within a little over a week five prisoners housed at Central Michigan tested positive for COVID-19. Unreported by MDOC and the media, the testing error that resulted in three positive COVID-19 cases being sent to CMCF was part of a much broader testing mistake. Emails resulting from a Freedom of Information Act request reveal that 27 prisoners (25 of which had tested positive for COVID-19) were sent from Egeler Reception and Guidance Center to at least four different facilities across the state including Central Michigan, Gus Harrison, Cotton and Women's Huron Valley correctional facilities, most of which were in the midst of fighting significant outbreaks (Michigan Department of Corrections 2020c). Furthermore, days after prisoners at Macomb received the results of mass testing, MDOC staff discovered that they had given 108 prisoners incorrect results: 54 prisoners received 
negative results when they were actually positive and 54 received positive results when they were actually negative. Those testing "positive" were moved to a housing unit specifically for COVID-19 while those who were given "negative" results remained in the general population for several days before the error was identified (Jackson 2020b). Serious errors in combination with ongoing transfers of prisoners between facilities unnecessarily exposed hundreds to COVID-19, further fueling the outbreaks at these facilities.

\section{MDOC COVID-19 Testing for Prisoners}

Towards the end of April 2020 it became apparent that mass testing was necessary, yet MDOC initially planned only to conduct testing at Lakeland and Cotton Correctional Facilities which house medically vulnerable populations (Jackson and Tanner 2020b). Lakeland was the first facility to receive mass prisoner testing, beginning around April 23. Stressing the need for systematic testing, 785 of the 1,403 inmates tested positive, yet 80 percent of prisoners who tested positive showed no symptoms at the time of testing (Samilton 2020b). On May 4, MDOC officials with the assistance of the Michigan National Guard began the process of testing every prisoner, starting with the six facilities in the state's rural Upper Peninsula (U.P.) (Michigan Department of Corrections 2020d). Although COVID19 was having a greater impact on facilities and communities in the state's Lower Peninsula, officials opted to prioritize testing at facilities where the virus was less prevalent. Of the 7,500 prisoners tested across the six U.P. facilities, only one positive case of COVID-19 was identified. Over the next two weeks, facility-wide testing continued across all MDOC facilities in the Lower Peninsula and concluded on May 22, 2020. The department's strategy of prioritizing testing in facilities without outbreaks allowed the virus to further flourish for an additional two to three weeks before mass testing was conducted at facilities such as Gus Harrison and Thumb (which were tested on May 12), Duane Waters and Women's Huron Valley (tested on May 13), Parnall and Egeler (tested on May 19) and Macomb (tested on May 20).

By June 2, 2020, most of the system-wide testing results were returned and made publicly available by the MDOC on their blog, which provides daily updated data on the total number of prisoner and staff infections at all MDOC facilities (Michigan Department of Corrections 2020e). At ten of the department's 29 facilities, no positive prisoner cases were identified while an additional eight facilities had fewer than ten positive prisoner cases. However, systematic testing revealed significant outbreaks of coronavirus at 11 of 29 MDOC facilities, which housed more than 3,896 of the total 3,918 positive prisoner cases. Located in the south-east quadrant of the state, infections in these facilities comprised 99 percent of all positive MDOC cases, and each reported at least one of 68 prisoner deaths from COVID-19 (see Table 1). 
Table 1 MDOC Prisoners Testing Positive for COVID-19 at Facilities with Outbreaks (as of June 2, 2020)

\begin{tabular}{lrccccc}
\hline Facility & Tested & Positive & Negative & Pending & \% Positive & Deaths \\
\hline Lakeland CF & 1430 & 793 & 637 & 0 & 56 & 23 \\
Robert G. Cotton CF & 1855 & 691 & 1164 & 0 & 37 & 4 \\
Gus Harrison CF & 1992 & 727 & 1263 & 2 & 37 & 4 \\
Parnall CF & 1574 & 495 & 1036 & 43 & 31 & 10 \\
Thumb CF & 992 & 289 & 654 & 49 & 29 & 7 \\
Duane Waters Health Center & 304 & 70 & 184 & 50 & 23 & 2 \\
Egeler Reception Center & 1370 & 281 & 1059 & 30 & 21 & 6 \\
Detroit Reentry Center & 125 & 22 & 58 & 45 & 18 & 2 \\
Macomb CF & 1354 & 236 & 1107 & 11 & 17 & 5 \\
Women's Huron Valley CF & 1939 & 273 & 1624 & 42 & 14 & 4 \\
Woodland CF & 337 & 19 & 318 & 0 & 6 & 1 \\
TOTAL & 13,272 & 3,896 & 9,104 & 272 & N/A & 68 \\
\hline
\end{tabular}

Source: Michigan Department of Corrections (2020e) "Total Confirmed Prisoner and Staff Cases to Date", MDOC Response and Information on coronavirus (COVID-19), Updated daily. Available online at https://medium.com/@ MichiganDOC/mdoc-takes-steps-to-prevent-spread-of-coronavirus-covid-19-250f43144337 (accessed on June 2, 2020).

As was known prior to mass testing, Lakeland (56 percent), Cotton (37 percent) and Parnall (31 percent) correctional facilities were all experiencing active COVID-19 outbreaks, with more than one third of the population testing positive. Yet testing also uncovered high percentages of positive cases at eight other MDOC facilities including Gus Harrison (37 percent), Thumb (29 percent), Duane Waters Health Center (23 percent), Egeler Reception Center (21 percent), Detroit Reentry Center (18 percent), Macomb (17 percent), Women's Huron Valley (14 percent) and Woodland Correctional Facility (6 percent).

Multiple facilities experienced numerous prisoner deaths including Lakeland (23 deaths), Parnall (10 deaths), Thumb (7 deaths), Egeler Reception Center (6 deaths) and Macomb (5 deaths), among others (Michigan Department of Corrections 2020e). Those who died from the virus were disproportionately over the age of 60 . Of the 68 deaths, 77 percent occurred among prisoners who were over $60(60 \mathrm{~s}(\mathrm{~N}=24), 70 \mathrm{~s}(\mathrm{~N}=24), 80 \mathrm{~s}(\mathrm{~N}=4))$, although included people in their 40s $(\mathrm{N}=3)$ and 50s $(\mathrm{N}=13)$ (Michigan Department of Corrections 2020f).

At Lakeland Correctional Facility, which provides geriatric housing for prisoners who are at least 50 years old and have a serious medical condition, half the population (more than 700 prisoners) are elderly or have chronic health conditions. Approximately 17 percent of prisoners at Lakeland are 65 and older (compared with 5 percent of all prisoners across the system), while 4 percent are age 75 and older (compared with 1 percent of all state prisoners). Within just one unit at 
Lakeland that houses 80 geriatric prisoners and 16 prisoner aides, 56 people (58 percent) tested positive. The majority of the 23 prisoners who died from the virus at Lakeland came from one of the facility's 16 geriatric units (Jackson and Tanner 2020b). About half the prisoners that died were serving life sentences for murder or other crimes and were unlikely to be released under any circumstance (Jackson and Tanner 2020c), yet others were incarcerated beyond their earliest release date and were only months away from re-entering society (Associated Press 2020).

In addition to conducting mandatory nasal swab testing to assess active infections of COVID-19, MDOC also offered optional antibody serology testing to prisoners throughout facilities during the second half of May 2020. Widespread testing revealed that prisoners at numerous facilities were previously infected by COVID-19, therefore resulting in antibodies to the virus (see Table 2).

Of the 7,905 prisoners tested for antibodies, 3,550 tested positive while 4,355 tested negative. Reaffirming the results of MDOC mandatory nasal swab testing, voluntary antibody blood testing indicated that outbreaks were concentrated at the previously identified 11 facilities. Antibody results from Parnall Correctional Facility, where most prisoners volunteered to be tested, revealed that 92 percent tested positive for antibodies for COVID-19, many of which were asymptomatic. More than half of those tested previously had COVID-19 at Lakeland (74 percent) and Macomb (66 percent), while at least one third of the population tested positive for antibodies at Woodland (41 percent), Women's Huron Valley (35 percent), Duane Waters Health Center (35 percent) and Gus Harrison (34 percent) (Michigan Department of Corrections 2020g).

Table 2 MDOC Prisoners Testing Positive for COVID-19 Antibodies at Facilities with Outbreaks (as of June 16, 2020)

\begin{tabular}{lrrrl}
\hline Facility & Tested & Positive & Negative & \% Positive \\
\hline Parnall CF & 1291 & 1187 & 104 & 92 \\
Lakeland CF & 740 & 549 & 191 & 74 \\
Macomb CF & 1246 & 820 & 426 & 66 \\
Detroit Reentry Center & 6 & 3 & 3 & 50 \\
Woodland CF & 29 & 12 & 17 & 41 \\
Women's Huron Valley CF & 345 & 120 & 225 & 35 \\
Duane Waters Health Center & 135 & 47 & 88 & 35 \\
Gus Harrison CF & 866 & 291 & 575 & 34 \\
Thumb CF & 651 & 147 & 504 & 23 \\
Egeler Reception Center & 567 & 119 & 448 & 21 \\
Robert G. Cotton CF & 1020 & 209 & 811 & 20 \\
TOTAL & 6,896 & 3,403 & 3,392 & N/A \\
\hline
\end{tabular}

Source: Michigan Department of Corrections (2020g) "COVID-19 Antibody Testing Results for Prisoners and Select Staff by Facility", June 25. Obtained via Freedom of Information Act Request. FOIA No. 20-3270. 
Racial Disparities in Positive COVID-19 Cases and Deaths among Prisoners

Researchers from the Marshall Project tried to assess the extent to which COVID19 is falling harder on Black prisoners yet were only able to obtain scant data from six states, including Michigan. By the end of May, Chammah and Meagher (2020) found that 48 percent of prisoners who had died were Black, compared with 40 percent of people who died overall in Michigan. Moreover, Black prisoners in Michigan also accounted for 49 percent of positive COVID-19 tests, while at the same time Black residents in the state as a whole comprised 31 percent of positive tests.

Confirming these findings, Michigan Department of Corrections (2020f) data obtained via Freedom of Information Act request on the racial demographics of positive prisoner cases from early June show that 53 percent were people of colour, including Asian $(\mathrm{N}=8)$, Black or African American $(\mathrm{N}=1,872)$, Hispanic or Latino $(\mathrm{N}=109)$, American Indian or Alaskan Native $(\mathrm{N}=50)$ and Native Hawaiian or Other Pacific Islander $(\mathrm{N}=2)$. The remaining 47 percent of positive cases were White $(\mathrm{N}=1,809)$ (see Table 3$)$.

The total number of prisoner deaths from COVID-19 by early June totaled 68 . Of this number, 49 percent were people of colour including Black $(\mathrm{N}=32)$ and Hispanic $(\mathrm{N}=1)$, while the remaining deaths were of White prisoners $(\mathrm{N}=35)$. However, Mahar (2019) notes that the MDOC inconsistently reports prisoner demographics on race and ethnicity, most commonly by classifying prisoners as Black or White, failing to regularly include a category for Latino/Hispanic and estimating the race of incarcerated people rather than allowing for self-reporting. Therefore, MDOC data on the racial demographics of positive cases and deaths from COVID-19 may be inaccurate or incomplete.

Table 3 Racial Demographics of MDOC Prisoners Testing Positive for COVID-19 (as of early June 2020)

\begin{tabular}{lcc}
\hline Race & Positive & Death \\
\hline Asian & 8 & \\
Black or African American & 1872 & 32 \\
Hispanic or Latino & 109 & 1 \\
American Indian or Alaskan Native & 50 & \\
Native Hawaiian or Other Pacific & 2 & 35 \\
Islander & 1809 & 68 \\
White & 3850 & \\
TOTAL & & \\
\hline
\end{tabular}

Source: Michigan Department of Corrections (2020f) "Racial Demographics of COVID + Offenders", Office of Research and Planning, FOIA No. 20-3269. 


\section{MDOC COVID-19 Testing for Staff}

Similar to other states across the country, Michigan was slow to implement voluntary testing for MDOC staff. Initially, staff were forced to seek testing elsewhere in the community and then independently report their positive results to their employer, often in the course of calling in sick (Marshall Project 2020). It was not until the end of May 2020 that MDOC began offering voluntary nasal swab and antibody testing for staff (Jackson 2020a). After more than 200 staff tested positive and two died from the virus, only then did MDOC began offering free tests to prison workers on weekends at limited locations (Aspinwall and Neff 2020). According to Byron Osborn, president of the Michigan Corrections Organization, the union representing correction officers, "[w]e're struggling with getting officers tested... We believe that the state ... [should] be proactive and kind of try to get in front of this too, so the rest of our facilities aren't impacted. We're advocating for staff to be tested" (Barr 2020). Not until May did MDOC began offering free, voluntary testing to all staff. Just over 2,000 of 12,000 total employees have been tested by the department as of late July (Jackson and Tanner 2020d).

As of June 2, 2020, of the state's more than 12,000 correction staff, MDOC reported 368 positive staff cases and two deaths across its 29 facilities and four additional administrative and operational facilities. Staff positive cases at the 11 facilities with outbreaks comprise 89 percent of all reported staff cases (see Table 4) (Michigan Department of Corrections 2020e).

Similar to the high percentage of positive cases among prisoners at facilities in south-east Michigan, staff also had the highest number of employees testing positive at Parnall (27 percent), Lakeland (13 percent), Macomb (10 percent) and Cotton (10 percent) correctional facilities.

In addition to nasal swab testing for COVID-19, MDOC also conducted limited voluntary antibody serology testing for staff as well. According to information from Michigan Department of Corrections (2020h), as of May 2, 2020, there were 12,030 total employees, of which 1,873 classified employees were tested and 97 were positive for COVID-19 antibodies (see Table 5).

Even though less than one third of staff at facilities with significant outbreaks voluntarily underwent antibody testing for COVID-19, data indicate that staff at multiple facilities tested positive for antibodies, meaning they were previously infected with the virus. Significant percentages of staff tested positive for antibodies at Parnall (32 percent of staff tested), Lakeland (25 percent), Macomb (19 percent), Women's Huron Valley (13 percent) and Detroit Reentry Center (10 percent) (Michigan Department of Corrections 2020h). As the data demonstrates, 
Table 4 MDOC Staff Testing Positive for COVID-19 at Facilities with Outbreaks (as of June 2, 2020)

\begin{tabular}{lcccc}
\hline Facility & Total Employees* & Positive & \% Positive & Deaths \\
\hline Parnall CF & 291 & 77 & 27 & \\
Lakeland CF & 266 & 34 & 13 & \\
Macomb CF & 333 & 33 & 10 & \\
Robert G. Cotton CF & 408 & 41 & 10 & \\
Detroit Reentry Center & 246 & 16 & 7 & 1 \\
Egeler Reception Center & 556 & 36 & 6 & \\
Gus Harrison CF & 469 & 32 & 6 & \\
Women's Huron Valley CF & 579 & 29 & 5 & \\
Thumb CF & 305 & 16 & 5 & \\
Woodland CF & 318 & 15 & 5 & \\
Duane Waters Health Center & N/A & N/A & N/A & \\
TOTAL & 3771 & 329 & & \\
\hline
\end{tabular}

Source: Michigan Department of Corrections (2018) 2018 Statistical Report, State of Michigan. Available online at www.michigan.gov/documents/corrections/MDOC_2018_Statistical_Report_-_2019.07.18_662129_7.pdf (accessed on June 15, 2020); Michigan Department of Corrections (2020e) "Total Confirmed Prisoner and Staff Cases to Date", MDOC Response and Information on coronavirus (COVID-19), Updated daily. Available online at https://medium.com/@MichiganDOC/mdoc-takes-steps-to-prevent-spread-of-coronavirus-covid-19-250f43144337 (accessed on June 2, 2020).

*Total employees by facility as of December 30, 2018.

Table 5 MDOC Staff Testing Positive for COVID-19 Antibodies at Facilities with Outbreaks (as of June 16, 2020)

\begin{tabular}{lcccccc}
\hline Facility & Total Employees* & Total Tested & \% Tested & Positive & Negative & \% Positive \\
\hline Parnall CF & 291 & 38 & 13 & 12 & 26 & 32 \\
Lakeland CF & 266 & 53 & 20 & 13 & 40 & 25 \\
Macomb CF & 333 & 43 & 30 & 8 & 35 & 19 \\
Women's Huron & 579 & 172 & 30 & 22 & 150 & 13 \\
Valley CF & & & & & & \\
Detroit Reentry Center & 246 & 33 & 13 & 4 & 29 & 12 \\
Woodland CF & 318 & 77 & 24 & 6 & 71 & 8 \\
Robert G. Cotton CF & 408 & 54 & 13 & 4 & 50 & 7 \\
Egeler Reception & 556 & 71 & 13 & 3 & 68 & 4 \\
Center & & & & & & \\
Gus Harrison CF & 469 & 73 & 16 & 1 & 72 & 1 \\
Thumb CF & 305 & 31 & 10 & 0 & 31 & 0 \\
TOTAL & 3771 & 645 & & 73 & 572 &
\end{tabular}

Source: Michigan Department of Corrections (2018) 2018 Statistical Report, State of Michigan. Available online at www.michigan.gov/documents/corrections/MDOC_2018_Statistical_Report_-_2019.07.18_662129_7.pdf (accessed on June 15, 2020); Michigan Department of Corrections (2020h) "Staff Antibody Testing by Facility". July 15. Obtained via Freedom of Information Act Request. FOIA No. 20-3372.

*Total employees by facility as of December 30, 2018. 
outbreaks at the 11 identified facilities also impacted staff as well, resulting in three deaths at different facilities by the start of August.

Michigan's leadership, in systematic coronavirus testing across its facilities, made an important first step, albeit a delayed one, towards stemming the growth of the virus. As the results of prisoner and staff COVID-19 nasal swab and antibody blood testing revealed, within weeks, thousands had been infected by the virus and dozens of prisoners had died; disproportionately taking a toll on Black and elderly prisoners. Delays in systematic testing at facilities with known outbreaks allowed the virus to fester for weeks, resulting in additional infections. Moreover, MDOC's ongoing policy of transferring prisoners even after testing positive for COVID-19 exposed countless numbers of prisoners and staff, a problem compounded by mistakes in testing and distributing results. Finally, the failure to systematically test MDOC staff continues to allow coronavirus to seep through the prison gates. Throughout the MDOC system, the rates of staff infections have continued to rise even as positive prisoner cases stabilized momentarily before beginning their ascent again in August 2020. While the spread of the virus has thus far remained primarily contained within prisons located in the south-east quadrant of the state, staff members at facilities located in less populated regions located in more northern regions of the state are now seeing rising infection numbers (Jackson and Tanner 2020d). As a result, new outbreaks are emerging in Michigan prisons such as the Muskegon Correctional Facility, which went from no positive cases to nearly 400 in under two weeks (Jackson 2020c; Michigan Department of Corrections 2020e). Without a consistent and mandatory screening regime, staff will continue to be the primary transmitters of infection from the outside world, endangering the lives of those incarcerated under their care.

\section{Discussion and Conclusion}

Flattening the curve for incarcerated populations requires the release of as many people as possible, as quickly as possible. Human rights and criminal justice reform organizations have advocated for decarceration as an essential means of preventing the spread of coronavirus behind bars. To avert an imminent catastrophe resulting in thousands of unnecessary deaths, Human Rights Watch (2020) has called for jail and prison populations to be reduced to the point where, at a minimum, all people can engage in social distancing in accordance with the authoritative guidelines (e.g. six feet or greater in all directions at all times) without relying on punitive quarantine measure that resemble solitary confinement. Offering recommendations for safely reducing prison populations, the 
Brennan Center for Justice (2020) urged governors to use their power to grant clemency in the form of pardons, commutations and reprieves; expand the use of good conduct credits; delay sentencing and incarceration; and limit the impact of criminal justice debt.

Despite compassionate release of high-profile white-collar criminals such as Paul Manafort and Michael Cohen, among others, most state and federal prisoners have not been as fortunate (Neff and Blakinger 2020). Excluding prisoners charged with felonies, violent offenses or sexual offenses, some governors have issued limited executive orders calling for the release of medically vulnerable people or those nearing completion of their sentence, although these orders have been allowed to expire in some states. However, no state officials opted to issue an order that would release all people who were determined to be medically vulnerable and/or nearing the completion of their sentence without regard to offense type (Widra and Hayre 2020). Failure to reduce prison populations could have catastrophic impacts that span beyond the prisons walls, including an additional 100,000 coronavirus deaths more than current estimates as a consequence of inaction (American Civil Liberties Union 2020). Stressing the interrelationship between public health and the health of incarcerated populations in the United States and around the world, Akiyama, Spaulding, and Rich (2020: 2077) contend " $[\mathrm{t}] \mathrm{o}$ promote public health, we believe that efforts to decarcerate, which are already under way in some jurisdictions, need to be scaled up; and associated reductions of incarcerated populations should be sustained."

As the dearth of state crime research on mass incarceration and structural racism attests, more analysis and advocacy on behalf of prisoners is desperately needed. Sparked by the death of George Floyd at the hands of the Minneapolis police, the movement for Black lives has recently reasserted its calls for racial justice and an end to systemic racism. Although activists have centered police violence at the forefront of the movement, the accumulated racial disadvantage plaguing prisons at the back end of the criminal justice system cannot be ignored. The callous neglect of the human rights of prisoners during the COVID-19 pandemic is not new, but rather is the result of decades of punitive sentencing policies that disproportionately target people of colour. Providing a wealth of opportunities for further state crime investigation and analysis, normalized punitive practices within the United States such as the death penalty, life-long sentences, solitary confinement, privatized prisons and services, and juvenile incarceration are forms of cruel and unusual punishment that are viewed as abhorrent by other countries. Executive release orders and legislative reforms are important measures for mitigating the immediate crisis of coronavirus, but they do not solve the pandemic of mass incarceration and the slow violence of 
state-organized race crime. Ultimately, the United States must embark on a permanent program of decarceration and prison abolition. To end the dual pandemics of mass incarceration and the spread of COVID-19 inside prisons, we must follow the lessons of abolitionist scholars such as Davis (2003), Gilmore and Kilgore (2019) and Gilmore (2020) and strive for a world beyond state-organized violence where prisons no longer exist.

The pervasive nature of White supremacy and institutional racism is not limited to prisons but instead permeates across many social institutions in the United States including housing, education, employment and health care. Similar to the crisis of mass incarceration, the disproportionate impact of coronavirus on racial minorities has unveiled the pre-existing condition of structural racism at the core of health inequities. Acknowledging the persistence of institutional racism, the Center for Disease Control (2020) identifies discrimination, health care access and utilization, occupation, housing, and educational, income and wealth gaps as contributing factors to increased risk of infection and mortality for racial and ethnic minorities. Government policy has directly and indirectly shaped racebased segregation in housing, schools, workplaces and health care facilities, resulting in higher rates of disease and premature death for minorities. The breadth of institutional racism provides fertile ground for advancing the concept of state-organized race crime, especially amidst the coronavirus pandemic. For example, racial disparities in the quality of care within nursing homes existed before the pandemic and continue to persist in coronavirus infection and death rates. Residents at care facilities with significant proportions of Black and Latino populations are twice as likely to be infected by coronavirus regardless of facility location, size or government rating (Gebeloff et al. 2020). Additionally, occupational differences across racial groups have resulted in higher COVID-19 mortality rates for Black workers who are more likely to be employed in occupations deemed essential (Rogers et al. 2020). Within the meatpacking and poultry processing industry, racial and ethnic minorities represent 61 percent of the workforce, yet comprised 87 percent of all meatpacking facility infections after President Trump signed an executive order requiring plants to stay open despite the risk of spreading COVID-19 (Waltenburg et al. 2020). Finally, as recent research has shown that even a small increase in air pollution leads to a large increase in the COVID-19 death rate (Wu et al. 2020), it becomes evident that insights from the field of environmental justice must be employed to understand the intersection of environmental racism and coronavirus. Avenues for future research such as these hold the potential to identify and interrupt dispersed, hidden and delayed forms of victimization resulting from state-organized race crimes during times of pandemic and beyond. 


\section{References}

Abbas, H. (2020) "Exclusive: Michigan prisoner describes dangerous conditions, lack of response by MDOC officials over COVID-19," Arab American News, 22 May. Available online at: www. arabamericannews.com/2020/05/19/exclusive-michigan-prisoner-describes-dangerous-conditionslack-of-response-by-mdoc-officials-over-covid-19/ (accessed 1 July 2020).

Abrams, et al. v. Chapman, et al. (2020) United States District Court in the E.D. of Michigan, Southern Division. Filed April 29, 2020. Case No. 20-11053.

Agar, J. (2020) "3 Michigan inmates with coronavirus sent to virus-free prison after lab mix-up, corrections official says", Mlive, 8 May. Available online at: www.mlive.com/news/grandrapids/2020/05/3-michigan-inmates-with-coronavirus-sent-to-virus-free-prison-after-lab-mix-upcorrections-official-says.html (accessed 1 July 2020).

Akiyama, M. J., Spaulding A. C., and Rich, J. D. (2020) "Flattening the Curve for Incarcerated Populations: Covid-19 in Jails and Prisons", New England Journal of Medicine, 382: 2075-2077. Available online at: www.nejm.org/doi/full/10.1056/NEJMp2005687 (accessed 1 July 2020).

Alexander, M. (2012) The New Jim Crow: Mass Incarceration in the Age of Colorblindness. New York: The New Press.

American Civil Liberties Union, West Virginia (2020) "Racial Disparities in Jails and Prisons: COVID19's Impact on the Black Community", 12 June. Available online at: www.acluwv.org/en/news/ racial-disparities-jails-and-prisons-covid-19s-impact-black-community (accessed 1 July 2020).

Angelotti, S. and Wycoff, S. (2010) Michigan's Prison Health Care: Costs in Context, Michigan Senate Fiscal Agency. Available online at: www.senate.michigan.gov/sfa/Publications/Issues/ PrisonHealthCareCosts/PrisonHealthCareCosts.pdf (accessed 1 July 2020).

Aspinwall, C. and Neff, J. (2020) "These Prisons Are Doing Mass Testing for COVID-19 And Finding Mass Infections" The Marshall Project, 24 April. Available online at: www.themarshallproject. org/2020/04/24/these-prisons-are-doing-mass-testing-for-covid-19-and-finding-mass-infections (accessed 1 June 2020).

Associated Press (2020) "Michigan Prisoner Awaiting Release Dies From COVID-19", 18 April. Available online at: www.usnews.com/news/best-states/michigan/articles/2020-04-18/michiganprisoner-awaiting-release-dies-from-covid-19 (accessed 1 June 2020).

Barr, L. (2020) "Over 5,000 corrections officers have contracted COVID-19" ABC News, 5 May. Available online at: https://abcnews.go.com/US/5000-corrections-officers-contracted-covid-19/ story?id=70520117 (accessed 1 June 2020).

Bradshaw, E. A. (2019) "Green State Crimes and Toxic Prisons: Synthesizing Environmental Harms at the Intersection of the Military and Prison Industrial Complexes", in Rothe, D. L. and Collins, V. E. ed. Explorations in Critical Criminology in Honor of William J. Chambliss. Boston: Brill.

Brennan Center for Justice (2020) "Letter to The Honorable Governors of the fifty states, Re: Governors' Executive Authority to Release Vulnerable People Who Pose No Risk to Public Safety from Incarceration", April 6. Available online at: http://rappcampaign.com/wp-content/uploads/ Brennan-Center-for-Justice-Letter-to-Governors-Covid-19.pdf (accessed 1 August 2020).

Bunting, W. C. (2015) "The High Fiscal Costs of Incarcerating the Elderly", in Roberts, S. K. ed. Aging in Prison: Reducing Elder Incarceration and Promoting Public Safety. New York: The Center for Justice at Columbia University.

Center for Disease Control (2020) "Health Equity Considerations and Racial and Ethnic Minority Groups", 24 July. Accessed online at: www.cdc.gov/coronavirus/2019-ncov/community/healthequity/race-ethnicity.html (accessed 28 October 2020). 
Chammah, M. and Meagher, T. (2020) "Is COVID-19 Falling Harder on Black Prisoner? Officials Won't Tell Us", The Marshall Project, 28 May. Available online at: www.themarshallproject. org/2020/05/28/is-covid-19-falling-harder-on-black-prisoners-officials-won-t-tell-us (accessed 1 June 2020).

Davis, A. (2003) Are Prisons Obsolete? New York: Seven Stories Press.

Egan, P. and Jackson, A. (2020) "Why Coronavirus Is Running Rampant in Michigan Prisons", Detroit Free Press, 5 April. Available online at: www.freep.com/story/news/local/michigan/2020/04/05/ coronavirus-spreading-fast-michigan-prisons/2938733001/ (accessed 1 June 2020).

Fellner, J. (2015) “Aging Behind Bars: Prison, Punishment, Parole and Human Rights”, in Roberts, S. K. ed. Aging in Prison: Reducing Elder Incarceration and Promoting Public Safety. New York: The Center for Justice at Columbia University.

Garcia Laboratory (2020) “Corrected Reports." Email from Rachelle Maurer, Laboratory Manager to Michigan Department of Corrections officials. 1 May. Obtained via FOIA request filed May 27, 2020. FOIA No. 20-3199.

Gebeloff, R., Richtel, M., Smith, M., Yourish, K., Dance, S., Fortier, J., and Parker, M. (2020) “The Striking Racial Divide in How Covid-19 Has Hit Nursing Homes", The New York Times, 10 September. Available online at: www.nytimes.com/article/coronavirus-nursing-homes-racial-disparity.html (accessed 28 October 2020).

Ghandnoosh, N. (2014) "Black Lives Matter: Eliminating Racial Inequity in the Criminal Justice System", The Sentencing Project. Available online at: https://sentencingproject.org/wp-content/ uploads/2015/11/Black-Lives-Matter.pdf (accessed 1 June 2020).

Gilmore, R. W. (2020) "The Case for Prison Abolition: Ruth Wilson Gilmore on COVID-19, Racial Capitalism and Decarceration”, Democracy Now! Available online at: www.democracynow. org/2020/5/5/ruth_wilson_gilmore_abolition_coronavirus (accessed 1 August 2020).

Gilmore, R. W. and Kilgore, J. (2019) "The Case for Abolition" The Marshall Project, June 19. Available online at: www.themarshallproject.org/2019/06/19/the-case-for-abolition (accessed 1 August 2020).

Gordon, A. (2006) "Abu Ghraib: Imprisonment and the War on Terror", Race and Class, 48(1): $42-59$.

Human Rights Watch (2012) Old Behind Bars: The Aging Prison Population in the United States. Available online at: www.hrw.org/sites/default/files/reports/usprisons0112webwcover_0_0.pdf (accessed 1 June 2020).

Human Rights Watch (2020) Averting an Imminent Catastrophe: Recommendations to US Local, State and Federal Officials to Covid-19 in Jails and Prisons. Available online at: www.hrw.org/ sites/default/files/supporting_resources/c19_detention_finalreport_43020.pdf (accessed 1 August 2020).

Jackson, A. (2020a) "Almost everyone at one Michigan prison tests positive for COVID-19 antibodies", The Detroit Free Press, 28 May. Available online at: www.freep.com/story/news/local/ michigan/2020/05/28/coronavirus-antibodies-michigan-parnall-correctional-facility/5270127002/ (accessed 1 June 2020).

Jackson, A. (2020b) "COVID-19 results for 108 prisoners mixed up at Macomb Correctional Facility", The Detroit Free Press, 3 June. Available online at: www.freep.com/story/news/local/michigan/2020/06/03/coronavirus-prisoners-macomb-correctional/3134951001/ (accessed 1 July 2020).

Jackson, A. (2020c) "West Michigan prison reports COVID-19 outbreak", The Detroit Free Press, 6 August. Available online at: www.freep.com/story/news/local/michigan/2020/08/06/michiganprison-covid-19-muskegon-correctional/3299082001/ (accessed 12 August 2020). 
Jackson, A. and Egan, P. (2020) "First Michigan prisoner tests positive for coronavirus", The Detroit Free Press, 23 March. Available online at: www.freep.com/story/news/local/michigan/2020/03/23/ first-prisoner-tests-positive-coronavirus/2896984001/ (accessed 1 June 2020).

Jackson, A. and Tanner, K. (2020a) "Infection rate at Michigan prison exceeds New York, Chicago jail hot spots." The Detroit Free Press, 15 April. Available online at: www.freep.com/story/news/ local/michigan/2020/04/16/infection-rate-michigan-prison-exceeds-new-york-chicago-jail-hotspots/2987935001/ (accessed 1 June 2020).

Jackson, A. and Tanner, K. (2020b) "Coronavirus cases at Michigan prison surge as widespread testing begins", The Detroit Free Press, 25 April. Available online at: www.freep.com/story/news/ local/michigan/2020/04/25/coronavirus-cases-michigan-prison-surge-widespread-testing-prison ers/3002811001/ (accessed 1 June 2020).

Jackson, A. and Tanner, K. (2020c) "Michigan ranks highest in nation for prisoner deaths from coronavirus." The Detroit Free Press, 9 May. Available online at: www.freep.com/story/news/local/ michigan/2020/05/09/prisoner-coronavirus-covid-19-deaths/3090182001/ (accessed 1 June 2020).

Jackson, A. and Tanner, K. (2020d) "Active COVID-19 cases in Michigan prisons are down, but experts say threat isn't over", The Detroit Free Press, 24 July. Available online at: www.freep.com/ story/news/local/michigan/2020/07/24/michigan-prisons-coronavirus-cases/5470839002/?utm _ source $=$ oembed\&utm_medium $=$ onsite\&utm_campaign $=$ storylines\&utm_content $=$ news\&utm term=4566614002 (accessed 1 August 2020).

Labelle, D. (2008) "Bringing Human Rights Home to the World of Detention", Columbia Human Rights Law Review, 40(1): 79-133.

LeBlanc, B. (2020) "Group seeking to restore 'good time' prison credits derailed by faulty signature count”, The Detroit News, 25 July. Available online at: www.detroitnews.com/story/news/ local/michigan/2020/07/25/good-time-prison-credit-ballot-plan-derailed-faulty-signaturecount $/ 5501371002 /$ (accessed 1 August 2020).

Levine, B. (2015) "10,000 fewer Michigan prisoners: Strategies to reach the goal", Citizens Alliance on Prisons and Public Spending. Available online at: www.safeandjustmi.org/wp-content/ uploads/2015/06/Executive_summary_10000_fewer_prisoners.pdf (accessed 1 August 2020).

Llanes, C. (2020) "Transportation officer in Detroit is first MDOC employee is first MDOC employee to die due to COVID-19", Michigan Radio, 1 April. Available online at: www.michiganradio.org/ post/transportation-officer-detroit-first-mdoc-employee-die-due-covid-19 (accessed 1 June 2020).

Mahar, A. (2019) “A Snapshot of Michigan's Prison Population”, Safe and Just Michigan, 6 August. Available online at: www.safeandjustmi.org/2019/08/06/a-snapshot-of-michigans-prison-popula tion/ (accessed 1 June 2020).

Marshall Project (2020) "A State-by-State Look at Coronavirus in Prisons." Available online at: www.themarshallproject.org/2020/05/01/a-state-by-state-look-at-coronavirus-in-prisons (accessed 1 August 2020).

Mauer, M. (1996) "The Truth about Truth in Sentencing", Corrections Today, 58(1): 51-59.

Mauer, M. and Nellis, A. (2018) The Meaning of Life: The Case for Abolishing Life Sentences. New York: The New Press.

Michigan Department of Corrections (2018) "2018 Statistical Report”, State of Michigan. Available online at: www.michigan.gov/documents/corrections/MDOC_2018_Statistical_Report_-_2019. 07.18_662129_7.pdf (accessed 15 June 2020).

Michigan Department of Corrections (2020a) "MDOC Halts All Visits at State Prisons", 13 March. Available online at: www.michigan.gov/coronavirus/0,9753,7-406-98163-521571--,00.html (accessed 1 June 2020). 
Michigan Department of Corrections. (2020b) "UPDATE- Two MDOC Employees Test Positive for COVID-19", 17 March. Available online at: www.michigan.gov/coronavirus/ 0,9753,7-406-98158-522022--,00.html (accessed 1 June 2020).

Michigan Department of Corrections (2020c) "Corrected Reports." Emails between Chief Medical Officer C.M. McIntyre Leon, Assistant Chief Medical Officer James Blessman, Wardens from Central Michigan, Gus Harrison, G. Robert Cotton and Women's Huron Valley Correctional Facilities, officials from Bureau of Health Care Services and other MDOC officials. 1-2 May 2020. Obtained via Freedom of Information Act Request. FOIA No. 20-3199.

Michigan Department of Corrections (2020d) "Michigan National Guard to aid Michigan Department of Corrections with COVID-19 testing", 2 May. Available online at: www.michigan.gov/corona virus/0,9753,7-406-98158-527870--,00.html (accessed 1 June 2020).

Michigan Department of Corrections (2020e) "Total Confirmed Prisoner and Staff Cases to Date", MDOC Response and Information on coronavirus (COVID-19), Updated daily. Available online at: https://medium.com/@MichiganDOC/mdoc-takes-steps-to-prevent-spread-of-coronavirus-covid19-250f43144337 (accessed 2 June 2020).

Michigan Department of Corrections (2020f) "Racial Demographics of COVID + Offenders", Office of Research and Planning, FOIA No. 20-3269.

Michigan Department of Corrections (2020g) “COVID-19 Antibody Testing Results for Prisoners and Select Staff by Facility”, 25 June 2020. Obtained via Freedom of Information Act Request. FOIA No. 20-3270.

Michigan Department of Corrections (2020h) "Staff Antibody Testing by Facility", 15 July 2020. Obtained via Freedom of Information Act Request. FOIA No. 20-3372.

Moloney, C. J. and Chambliss, W. J. (2014) "Slaughtering the Bison, Controlling Native Americans: A State Crime and Green Criminology Synthesis", Critical Criminology, 22(3): 319-338.

Neff, J. and Blakinger, K. (2020) "Michael Cohen and Paul Manafort Got to Leave Federal Prison Due to COVID-19. They're The Exception”, The Marshall Project, 21 May. Available online at: www. themarshallproject.org/2020/05/21/michael-cohen-and-paul-manafort-got-to-leave-federal-prisondue-to-covid-19-they-re-the-exception (accessed 1 August 2020).

Nellis, A. (2016) "The Color of Justice: Racial and Ethnic Disparity in State Prisons", The Sentencing Project. Available online at: www.sentencingproject.org/publications/color-of-justice-racial-andethnic-disparity-in-state-prisons/ (accessed 1 June 2020).

Nellis, A. (2017) "Still Life: America's Increasing Use of Life and Long-Term Sentences", The Sentencing Project. Available online at: www.sentencingproject.org/wp-content/uploads/2017/05/ Still-Life.pdf (accessed 1 June 2020).

Nixon, R. (2011) Slow Violence and the Environmentalism of the Poor. Cambridge, MA: Harvard University Press.

Pew Center on the States. (2012) Time Served: The High Cost, Low Return of Longer Prison Terms. Available online at: www.pewtrusts.org/ /media/legacy/uploadedfiles/wwwpewtrustsorg/reports/ sentencing_and_corrections/prisontimeservedpdf.pdf (accessed 1 June 2020).

Rahal, S. (2020) "Prisoner dies in cell, COVID-19 virus spreads to 200 inmates in Michigan", The Detroit News, 4 April. Available online at: www.detroitnews.com/story/news/local/michi gan/2020/04/04/michigan-first-prisoner-death-coronavirus-covid-19-200-inmates/2947586001/ (accessed 1 June 2020).

Rogers, T. N., Rogers, C. R., VanSant-Webb, E., Gu, L. Y., Yan, B., and Qeadan, F. (2020) "Racial Disparities in COVID-19 Mortality Among Workers in the United States", World Medical Health and Policy, 12(3): 311-327. 
Rothe, D. (2006) "The Masquerade of Abu Ghraib: State Crime, Torture, and International Law," Ph.D. dissertation, Department of Sociology, Western Michigan University, Kalamazoo, MI.

Rothe, D. L., Kramer, R. C., and Mullins, C. W. (2009) "Torture, Impunity, and Open Legal Spaces: Abu Ghraib and International Controls", Contemporary Justice Review: Issues in Criminal, Social, and Restorative Justice, 12(1): 27-43.

Safe and Just Michigan (2019) "Old, sick and expensive: The graying of Michigan's prison population", 21 March. Available online at: www.safeandjustmi.org/2019/03/21/old-sick-and-expensivethe-graying-of-michigans-prison-population/ (accessed 1 June 2020).

Saloner, B., Parish, K., Ward, J., DiLaura, G., and Dolovich, S. (2020) "Research Letter: COVID-19 Cases and Deaths in Federal and State Prisons", JAMA, 8 July. Available online at: https://jamanet work.com/journals/jama/fullarticle/2768249 (accessed 1 August 2020).

Samilton, T. (2020a) "Teachers still have to report to state prisons despite COIVD-19." Michigan Radio, 30 March. Available online at: www.michiganradio.org/post/teachers-still-have-reportstate-prisons-despite-covid-19 (accessed 1 June 2020).

Samilton, T. (2020b) "MDOC tries to separate most vulnerable inmates from COVID-19 positive inmates", Michigan Radio, 27 April. Available online at: www.michiganradio.org/post/mdoc-triesseparate-most-vulnerable-inmates-covid-19-positive-inmates-0 (accessed 1 June 2020).

Sawyer, W. and Wagner, P. (2020) "Mass Incarceration: The Whole Pie 2020." Prison Policy Institute, 24 March. Available online at: www.prisonpolicy.org/reports/pie2020.html (accessed 1 August 2020).

Schrantz, D., DeBor, S., and Mauer, M. (2018) "Decarceration Strategies: How 5 States Achieved Substantial Prison Population Reductions", The Sentencing Project. Available online at: www. sentencingproject.org/publications/decarceration-strategies-5-states-achieved-substantial-prisonpopulation-reductions/ (accessed 1 June 2020).

Smeulers, A. and van Niekerk, S. (2009) "Abu Ghraib and the War on Terror: A Case Against Donald Rumsfeld?", Crime, Law and Social Change, 51:327-349.

State of Michigan (2020) "Executive Order 2020-29 (COVID-19)", The Office of Governor Gretchen Whitmer, 29 March. Available online at: www.michigan.gov/whitmer/0,9309, 7-387-90499_90705-523422--,00.html (accessed 1 August 2020).

U.S. Department of Justice, Office of Justice Programs, Bureau of Justice Statistics (2015) Medical Problems of State and Federal Prisoners and Jail Inmates, 2011-2012. Available online at: www. bjs.gov/content/pub/pdf/mpsfpji1112.pdf (accessed 1 June 2020).

U.S. Department of Justice, Office of Justice Programs, Bureau of Justice Statistics (2016) Aging of the State Prison Population, 1993-2013. Available online at: www.bjs.gov/content/pub/pdf/aspp9313. pdf (accessed 1 June 2020).

UCLA Prison Law and Policy Program (2020) "Covid-19 Behind Bars Data Project." Available online at: https://law.ucla.edu/academics/centers/criminal-justice-program/ucla-covid-19-behindbars-data-project (accessed 1 August 2020).

Wagner, P. and Sawyer, W. (2018) "States of Incarceration: The Global Context 2018", Prison Policy Initiative. Available online at: www.prisonpolicy.org/global/2018.html (accessed 1 August 2020).

Wallace, M., Hagan, L., Curran, K. G., et al. (2020) "COVID-19 in Correctional and Detention Facilities: United States, February-April 2020", MMWR Morbidity and Mortality Weekly Report (MMWR), 69: 587-590.

Waltenburg, M. A., Victoroff, T., Rose, C. E., et al. (2020) "Update COVID-19 Among Workers in Meat and Poultry Processing Facilities- United States, April-May 2020", Morbidity and Mortality Weekly Report, 10 July. Available online at: www.cdc.gov/mmwr/volumes/69/wr/mm6927e2.htm (accessed 28 October 2020). 
Ward, G. (2015) "The Slow Violence of State Organized Race Crime", Theoretical Criminology, 19(3): 299-314.

Widra, E. and Hayre, D. (2020) “Failing Grades: States' Responses to COVID-19 in Jails and Prisons", Prison Policy Initiative, 25 June. Available online at: www.prisonpolicy.org/reports/failing grades.html (accessed 1 August 2020).

Williams, T., Weiser, B., and Rashbaum, W. (2020) “'Jails Are Petri Dishes': Inmates Freed as the Virus Spreads Behind Bars", The New York Times, March 30. Available online at: www.nytimes. com/2020/03/30/us/coronavirus-prisons-jails.html (accessed 1 June 2020).

Wu, X., Nethery, R. C., Sabath, M. B., Braun, D., and Dominici, F. (2020) “Air Pollution and COVID19 Mortality in the United States: Strengths and Limitations of an Ecological Regression Analysis", Science Advances, 6(45). Available online at: https://advances.sciencemag.org/content/6/45/ eabd4049 (accessed 1 November 2020).

Yantus, A. (2014) "Sentence Creep: Increasing Penalties in Michigan and the Need for Sentencing Reform", University of Michigan Journal of Law Reform, 47(3): 64-696.

Yantus, A. (2017) "Michigan Sentencing Law: Past, Present and Future”, Federal Sentencing Reporter, 30(2): 146-154. 